\title{
1. Introduction: big questions for small technologies
}

\author{
Graeme Hodge, Diana Bowman and \\ Karinne Ludlow
}

\section{INTRODUCTION}

There is now much chatter about nanotechnology. Discussions are beginning to leave the boardrooms and science laboratories and enter the supermarkets. The term 'nanotechnology' encompasses an emerging family of heterogeneous technologies ${ }^{1}$ including 'nanosciences' and 'nanotechnologies' enabling the manipulation of matter at the atomic level (Drexler et al., 1993). Nanotechnology is defined by its scale - the nanometre (nm) or one billionth $\left(10^{-9}\right)$ of a metre. Conceptually, nanotechnology refers to the ability to control the composition of molecules and atoms, within the range of $1.0 \mathrm{~nm}$ to $100 \mathrm{~nm}$ (Wood et al., 2003), potentially enabling scientists to create specific molecular structures and devices (Forrest, 1989).

It has been heralded as a 'revolutionary' new technology and a key economic driver for the twenty-first century. The emergence of nanotechnology promises significant social benefits, including enhancements in medical diagnosis and health treatments, more efficient energy sources, lighter, faster and cheaper materials and electronic products, and even cleaner water on a global scale (Perkel, 2002; Wood et al., 2003; Roco, 2003; Royal Society and Royal Academy of Engineering (RS-RAE), 2004). With its economic value estimated at \$US1 trillion by 2015 (Roco and Bainbridge, 2001), the strategic significance of this emerging technology has already been identified by the public and private sectors alike. Lux Research (2006), for instance, estimates that total global nanotechnology research and development (R\&D) investment in 2005 alone was in the vicinity of \$US9.6 billion.

While the technology's origins can be traced back to Richard Feynman's famous 1959 lecture, 'There's plenty of room at the bottom', the word 'nanotechnology' itself was not coined until 1974 when scientist Norio Taniguchi used the word to refer to the ability to manipulate matter at the atomic level (Taniguchi, 1974). Since this time, breakthroughs in the technology have 
continued, although separating the science from science fiction has sometimes been difficult. Today nanotechnology is considered by many commentators as a 'platform' (ETC Group, 2003; 2005) or a potentially 'disruptive' technology (Department of Trade and Industry and Office of Science and Technology, 2002; ABC Radio National, 2004), with the capacity to cut across, and in some cases, re-write traditional sectoral boundaries. The rapid advance and commercialization of this family of technologies, however, presents a myriad of complex policy considerations, which promise to challenge existing ethical, legal and social (ELS) frameworks.

\section{NANOTECHNOLOGY IS ALREADY HERE}

The commercial production of nano-scale applications has already begun with the Environmental Law Institute (ELI) (2005) estimating that between 500-700 products incorporating simple passive nano-scale particles, compounds and composites are already available in the market place. ${ }^{2}$ Innovative nano-products currently finding their way onto retail shelves and into our homes include, for example, cosmetics (L'Oreal's Revita Life face and neck cream), therapeutic goods (the Australian Cancer Council's Plus Clear Zinc SPF30+ sunscreen), foods (Royal BodyCare's Slim Shake), clothing (Eddy Bauer's stain resistant shirt) and sporting goods (Babolat's Drive tennis racket) to name just a few (Woodrow Wilson, 2006).

While nanotechnology is arguably an extension of traditional techniques within the fields of engineering, biology, chemistry and physics, its novelty lies in the purposeful and precise manipulation and control of atoms and molecules in order to exploit the unique properties of materials that emerge at the nanoscale (Balbus et al., 2005). At this scale, the classic laws of physics are no longer applicable, resulting in novel properties and functions (RS-RAE, 2004). Specifically, materials at the nanoscale, relative to the same material at a larger size, have significantly different chemical reactivity, electrical conductivity, strength, mobility, solubility, magnetic and optical properties (RS-RAE, 2004; Swiss Re, 2004). The ETC Group (2003: 14) suggest that 'by tailoring the structure of materials at the nano-scale, it is possible to engineer novel materials that have entirely new properties never before identified in nature'. The use of carbon nanotubes (CNTs) in the auto exterior by General Motors in the Chevrolet Impala is one example. CNTs are stronger than steel, while being significantly lighter (ETC Group, 2003). Another example is self-cleaning bathroom surfaces which incorporate nanoscale titanium dioxide molecules to break down organic compounds and kill microbes (University of New South Wales, 2006). A further example aimed at personal use is ZinClear ${ }^{\mathrm{TM}}$, nanofine 
zinc oxide molecules that are used to create transparent sunscreen, while providing broad spectrum UV protection (Advanced Nanotechnology, 2005).

Putting such properties of these products aside, however, the unpredictability and novelty of manufactured nanoparticles has also seen commentators such as Balbus et al. (2005: 65) suggesting that:

these novel properties may pose new risks to workers, consumers, the public and the environment. The few data now available give cause for concern: Some nanomaterials appear to have the potential to damage skin, brain, and lung material, to be mobile or persistent in the environment, or to kill micro-organisms (potentially including ones that constitute the base of the food web).

Yet, as noted by the Environmental Law Institute (ELI) (2005: 3), 'even as nanotech products find their way to store shelves, little is known about the risk associated with their manufacture, use, and disposal'.

Moreover, nanotechnology is threatening to evolve in new directions. Long-term ideals for nanotechnology are certainly the most elaborate, challenging and speculative, but they also look rather like an approaching era of 'science fiction'. Drexler $(1986,2001)$ argues that this phase of development, coined 'molecular manufacturing', will be underpinned by the creation of computer directed nano-scale robots capable of precise manipulation of atoms to form complex atomic devices and machines. Such 'nano-bots' may in future travel through the bloodstream seeking and killing off cancer cells, or assist with the regeneration of healthy cells. At the opposite extreme, it may also be possible to use, for military purposes, nanobots to detect motion in a field and transmit signals many miles away, or even achieve 'programmable' genocide (Gubrud, 1997). Drexler's vision is that such robots, known as 'assemblers', will have the ability to selfreplicate, or clone themselves, and have the subsequent ability to work in unison to build macro-scale devices en masse. While commentators such as Whiteside and Love (2001) and Smalley (2001) have dismissed these ideas as 'futuristic hype', such a nanotechnology-based era nevertheless captures one exciting conceptual possibility. Importantly, the idea of 'fabrication from a molecular level of virtually any material or structure' (Wood et al., 2003: 1) continues to have dramatic psychological appeal and power for many.

This cursory review suggests that while this emerging family of technologies offers numerous promises and benefits, an opportunity also exists, as with all technologies, for significant social, political and scientific problems to emerge. It would therefore appear that the ELS impacts posed by nanotechnology must be clarified, as we learn to intelligently govern this technological phenomena and its commercial applications. 


\section{GOVERNANCE CHALLENGES}

A wide range of both policy and regulatory challenges currently exist for governments. In terms of policy, the continuing search for economic growth has seen governments welcoming the promises of nanotechnology with open arms. It suggests new possibilities, and not surprisingly, attracts large investments in research and development. But serious unanswered policy questions abound. To what degree should a government explicitly support nano-development or should it remain neutral? Should promising technological developments attract scarce public resources or rely on private investments? How should military research in these technologies, traditionally more secret than civilian research, be supported? And how should the comments of those who argue that 'reconfiguring the basic building blocks of matter is akin to playing God' be regarded in today's secular state?

'Nanotechnology' has all the makings of a classic public policy problem. There is a certain slipperiness to even defining nanotechnology itself. It 'has become a buzzword' and 'means different things to different people', as Berube (2004: 185) nicely put it. Not surprisingly, there are multiple ways of defining 'the nanotechnology problem' - or indeed attempting to define whether there is indeed a 'problem' there at all. Government is attempting to meet multiple goals at once - on the one hand encouraging economic development, ${ }^{3}$ while on the other ensuring that public safety, ethical standards and environmental integrity is maintained within a cohesive society. There is also a wide array of knowns and unknowns in terms of the science, as well as hopes and aspirations. At the government's fingertips there are decision tools and models to assist with policy choices and trade-offs. ${ }^{4}$ And these days, governments have a preference for using markets of private actors where possible rather than centrally designed bureaucratic policy solutions. There is also a range of competing interests at play. On one hand private companies are vying to sell new 'wonder' products that promise to increase revenues and profits, and on the other, unsuspecting and trusting consumers are believing the half truths put out under the commercial philosophy of smart 'marketing'.

In developing nanotechnology policy, governments are left balancing the realities of scientific progress and commercial demands against both entrepreneurial commercial scientific fiction and the rhetorical grenades of 'nano-pessimists' on the other. In shaping the policy middle ground, governments seek (at least in theory) to ensure that the public interest is met. They listen intently and aim to avoid repeating policy history. Citizens do not want a repeat of the past whereby it took governments 60 years to act after we first became aware that asbestos (the 'wonder-material' of the 
twentieth century) was linked to the deaths of workers participating in the asbestos industry. ${ }^{5}$ But equally, neither would citizens have confidence in a government which acted like the Church in the fifteenth and sixteenth centuries when it attempted to outlaw the 'dangerous' new technology of Gutenberg's printing press. Even the potential for a middle ground stance, a third way if you like, has also had high risks if we learn from the lack of public engagement, education and debate over genetically modified (GM) foods in the past decade. On this matter, the colourful 'Frankenfoods' label during the commercialization of GM foods resulted in a populist consumer and political backlash against the technology, forcing industry onto the defensive and leaving the European Union a 'GMO free' zone.

Citizens have rightly become wary of overblown claims from new technologies. As Rayner (2004) remarks, genetically modified (GM) crops, according to President George W. Bush and biotechnology companies, would 'end world hunger', and new information and communication technologies would put the world on the 'information superhighway'. The reality has been far more modest. World hunger has continued under the weight of the international political economy underpinned by personal indifference and selfishness. Likewise, the global 'digital divide' is now the topic of conversation for much of the world rather than the gift of a superhighway.

Clearly, technological pressures on policy all lead to a requirement for balance, with action. And as with other policy arenas, governments will sometimes choose to lead while at other times, they will lag. But whose values should be leading here, and whose should lag?

In a sense, the emergence of 'revolutionary' technological advances is not a new policy challenge for governments, as these have played a central role in the nineteenth and twentieth centuries. However, while these new technologies continue to show the potential to advance human kind and serve the citizenry, it is also true that 'social science often struggled to keep pace with new emerging technologies', as MacNaghten et al. (2005: 268-9) remark. Also, central to the government's challenge of promoting nanotechnology, while protecting citizens from new risks and uncertainties, will be the ability of governments to acknowledge not only the scientific issues, but also the public's evolving attitudes to ELS issues (House of Lords, 2000; Hodge and Bowman, 2004; Turk, 2005). Indeed, in relation to science and society:

policy makers will find it hard to win public support on any issue with a scientific component, unless the public's attitude and values are recognised, respected and weighed along with the scientific and other factors. (House of Lords, 2000: 2)

So while the primary focus for nanotechnology has in the past been on the coordination and funding of R\&D initiatives, in conjunction with the 
commercialization of nano-products, increasing attention is now being paid to the wider impacts of nanotechnology. This has included, for example, citizen policy engagement practices and questions of how best to govern the technology.

The wake up call for how this technology might best be regulated came with the release of the RS-RAE's (2004) seminal report. This has acted as a catalyst for renewed regulatory discussion. The question of whether and how to regulate nanotechnology is in itself not new, having been canvassed by Forrest (1989) some 15 years earlier. Despite the futuristic nature of nanotechnology at that time, Forrest (1989: 1) contended that 'the development of nanotechnology ... will seriously challenge the ability of our regulatory systems to respond quickly and maintain the critical balance between dangers and benefits'. This assertion led Forrest (1989) to conclude that for the safe development of nanotechnology, governments would be required to explore a range of flexible nano-specific regulatory frameworks, in which the varying degrees of regulatory control exercised would be dependent on each phase of development.

However, nano-specific regulatory frameworks are not the only possible response. Regulatory responses to earlier emerging technologies provide a range of possible models. These spread across a continuum, flowing from absolute prohibition by the state at one extreme as, for example, has occurred with human reproductive cloning in many jurisdictions, to no specific regulation at all at the other extreme. An example of the latter is the response in most cases, to the Internet where only in relation to a few discrete issues such as pornography and domain names, has there been any attempt at regulation. Travelling along the continuum, starting with absolute prohibition, comes regulation through government licensing as commonly occurs with pharmaceuticals. Next along the continuum is professional regulation through either prohibition of certain technologies (one of the best known examples of which is the moratorium on certain genetic modification techniques introduced by molecular biologists following the 1975 Asilomar conference) or licensing. Closer to the no specific regulation extreme, are self-regulation models, where the actors determine how the technology should be regulated, perhaps referring to codes of conduct or guidelines issued by their profession or other advisory committees.

Where nanotechnology will fit on this continuum in future is hard to predict. Much can be learnt from earlier technologies and many papers have begun doing that analysis (Einsiedel and Goldenberg, 2004; Mehta, 2004; Brumfiel, 2003; Wolfson, 2003). Nevertheless, it will largely be determined by events that are almost impossible to predict: public reaction and its input into decision making, the media's portrayal of the technology and the manner in which industry itself behaves and provides information. 
As Kearnes et al. (2006: 303) point out, 'new technologies often operate as nodal points around which wider public concerns condense. Such processes of "condensation" are inherently unpredictable.' Further, as with all emerging technologies, the risks and consequences of adopting nanotechnology are uncertain. All of this must be mapped onto the time in history when nanotechnology is entering the regulatory arena. As noted above, the public is nowadays more sophisticated in its demands of regulation but also more sceptical of those making scientific predictions and regulatory decisions. And scientists have also learnt lessons from the past. In particular they have learned of the danger of stigmatization where, in the midst of support for an emerging technology such as genetic modification, the scene was set for greater distrust by the public rather than strengthened confidence (Hindmarsh and Gottweiss, 2006).

\section{THIS BOOK}

The 'nanotechnology phenomenon' is currently the subject of an increasing number of books. Relevant arenas include the military (Ratner and Ratner, 2003; Altmann, 2006), chemical advances (Rietman and Andrews, 2001; Cao, 2004), materials (Vacca, 2006), ethical and social issues (Roco and Bainbridge, 2001; Hunt and Mehta, 2006) and philosophy and the politics of science (Baird et al., 2004) to name just a few. However, books focusing on the manner in which governments might sensibly govern this technology have been less visible. Jasanoff (2005) has looked at the manner in which governments treat science and technology in general within their policy making and regulatory frameworks, and is one valuable contribution here.

Bearing this in mind, one might ask 'why a book on nanotechnology and nanotechnology regulation so early in its development cycle, when so much remains undefined or unknown'? The reasons are threefold. First, there is a need to critically examine and articulate the consistent ethical, social and democratic issues being raised by nanotechnology across a number of different disciplines, and jurisdictions around the globe. These issues are likely to underpin the future of nanotechnology policy debate and become crucial prerequisites to the forthcoming regulatory challenges. Second, by adopting multi-jurisdictional and multi-disciplined lenses, it is now possible to begin the process of defining the nanotechnology regulatory frontiers that may be increasingly important in the coming 'nano-age'. Third, by drawing together international academic views, this edited book can begin to highlight common regulatory questions, issues and problems that jurisdictions are facing as they grapple with the regulatory challenges created by nanotechnology. 
So, if we were to begin thinking about regulatory frontiers in which nanotechnology may grow, an obvious, although not so often acknowledged starting point might be to more accurately define the subject matter. How then may nanotechnology be best defined?

\section{DEFINING NANOTECHNOLOGY}

'Nano', the Greek word for dwarf, refers to size, and while conceptually nanotechnology is defined by this scale, there has been little consensus on a universally accepted definition of nanotechnology. This is best illustrated by Table 1.1, which provides 18 examples of different definitions for nanotechnology. Looking down this table, five characteristics appear to be central to the question of definition:

1. Size: from around $100 \mathrm{~nm}$ down to less than $0.1 \mathrm{~nm}$.

2. Range of technologies: imaging, measuring, modelling and manipulating matter.

3. Multi-disciplinarity: including for instance, physical, chemical and biological, with each being purposefully 'engineered'.

4. Size dependent novel properties and functions.

5. The control and purposeful manipulation of matter at the atomic scale.

We might also add a raft of other characteristics to these, such as those suggested by Suchman (2002) including; invisibility, the potential microlocomotion of nano-scale robots, and self-replication of nano-scale robots through atom-by-atom construction. But the point is clear. While there are several common characteristics within definitions of nanotechnology, multiple syntaxes remain.

Definitional matters are not simple. For example, Schummer (2004) notes the tautology of nanotechnology as being defined by the nanoscale size of objects. He also points out the fact that using this size criteria alone, it is difficult to find any kind of matter that would not qualify as an object of nanoscale research. Furthermore, while the celebrated nanomaterial 'buckminsterfullerine' measures $1.4 \mathrm{~nm}$ in unit cell length, sugar (glucose), gypsum, vitamin C, pepsin, cholesterol and the flavour vanillin similarly all measure between 1 and $30 \mathrm{~nm}$ in length. In other words, the nanoscale criteria of itself is hardly anything new. And using Schummer's listing, neither is it necessarily novel.

What is also not evident in Table 1.1 are the huge disparities between the ideas and visions of the various nanotechnology writers. Schummer 
Table 1.1 Defining nanotechnology

\begin{tabular}{|c|c|}
\hline Source & Definition of nanotechnology/nanotechnologies \\
\hline Aitken et al. (2004: v) & $\begin{array}{l}\text { Nanotechnology is a broad interdisciplinary area of } \\
\text { research, development and industrial activity which has } \\
\text { been growing rapidly world wide for the past decade. } \\
\text { It is a multidisciplinary grouping of physical, chemical, } \\
\text { biological, engineering and electronic, processes, materials, } \\
\text { applications and concepts in which the defining } \\
\text { characteristic is one of size }\end{array}$ \\
\hline Allianz (2005: 3) & $\begin{array}{l}\text { The term nanotechnology describes a range of } \\
\text { technologies performed on a nanometer scale with } \\
\text { widespread applications as an enabling technology in } \\
\text { various industries. Nanotechnology encompasses the } \\
\text { production and application of physical, chemical and } \\
\text { biological systems at scales ranging from individual atoms } \\
\text { or molecules to around } 100 \mathrm{~nm} \text {, as well as the integration } \\
\text { of the resulting nanostructures into larger systems }\end{array}$ \\
\hline Crandall (1996: 1) & $\begin{array}{l}\text { Nanotechnology is 'the art and science of building } \\
\text { complex, practical devices with atomic precision' }\end{array}$ \\
\hline ELI (2005: 1) & $\begin{array}{l}\text { Nanotechnology is the science and technology of } \\
\text { controlling matter at the nanoscale }\end{array}$ \\
\hline EPA (2005: 4) & $\begin{array}{l}\text { Nanotechnology is defined as: research and technology } \\
\text { development at the atomic, molecular, or macromolecular } \\
\text { levels using a length scale of approximately } 1 \text { to } 100 \mathrm{~nm} \text { in } \\
\text { any dimension, the creation and use of structures, devices } \\
\text { and systems that have novel properties and functions } \\
\text { because of their small size; and the ability to control or } \\
\text { manipulate matter on an atomic scale }\end{array}$ \\
\hline ETC Group (2003: 8) & $\begin{array}{l}\text { Generally, nanotechnology refers to mechanical } \\
\text { engineering on a molecular scale, but it is a slippery and } \\
\text { ambiguous term }\end{array}$ \\
\hline $\begin{array}{l}\text { European } \\
\quad \text { Commission (2004: } 3)\end{array}$ & $\begin{array}{l}\text { Nanotechnologies refer to technologies of the very } \\
\text { small, with dimensions in the range of nanometers }\end{array}$ \\
\hline Loder (2005: 3) & $\begin{array}{l}\text { Nanotechnology is generally agreed to cover objects } \\
\text { measuring from } 1 \text { to } 100 \mathrm{~nm} \text {, though the definition is } \\
\text { somewhat arbitrary. Some people include things as small } \\
\text { as } 0.1 \mathrm{~nm} \text {, which is about the size of the bond between two } \\
\text { carbon atoms. At the other end of the range, in objects } \\
\text { larger than } 50 \mathrm{~nm} \text { the laws of classical physics become } \\
\text { increasingly dominant }\end{array}$ \\
\hline
\end{tabular}

Lux Research (2005: 1) Nanotechnology is the purposeful engineering of matter at scales of less than $100 \mathrm{~nm}$ to achieve size-dependent properties and functions 


\section{Table 1.1 (continued)}

\begin{tabular}{|c|c|}
\hline Source & Definition of nanotechnology/nanotechnologies \\
\hline Mehta (2004: 34) & $\begin{array}{l}\text { Nanotechnology involves creating and manipulating } \\
\text { organic and inorganic matter at the nanoscale }\end{array}$ \\
\hline $\begin{array}{l}\text { National } \\
\text { Nanotechnology } \\
\text { Initiative (2001) }\end{array}$ & $\begin{array}{l}\text { Nanotechnology is the understanding and control of } \\
\text { matter at dimensions of roughly } 1 \text { to } 100 \mathrm{~nm} \text {, } \\
\text { where unique phenomena enable novel applications. } \\
\text { Encompassing nanoscale science, engineering and } \\
\text { technology, nanotechnology involves imaging, } \\
\text { measuring, modelling and manipulating matter at } \\
\text { this length scale }\end{array}$ \\
\hline Pinson (2004: 282) & $\begin{array}{l}\text { Generally, nanotechnology is the ability to measure, } \\
\text { organize, and manipulate matter at the atomic and } \\
\text { molecular levels }\end{array}$ \\
\hline $\begin{array}{l}\text { Prime Minister's } \\
\text { Science, Engineering } \\
\text { and Innovation } \\
\text { Council }(2005: 2)\end{array}$ & $\begin{array}{l}\text { Nanotechnology is engineering at the molecular } \\
\text { (groups of atoms) level. It is the collective term for a } \\
\text { range of technologies, techniques and processes that } \\
\text { involve the manipulation of matter at the smallest } \\
\text { scale (from } 1 \text { to } 100 \mathrm{~nm}-1 / 10000 \text { of the thickness of } \\
\text { a human hair) }\end{array}$ \\
\hline Reynolds (2002: 2) & $\begin{array}{l}\text { Put simply, nanotechnology is a technology for making } \\
\text { things by placing atoms precisely where they are supposed } \\
\text { to go }\end{array}$ \\
\hline Roco (2003: 337) & $\begin{array}{l}\text { Nanotechnology is the ability to work at the atomic, } \\
\text { molecular and supramolecular levels (on a scale of } \sim 1-100 \\
\mathrm{~nm} \text { ) in order to understand, create and use material } \\
\text { structures, devices and systems with fundamentally new } \\
\text { properties and functions resulting from their small } \\
\text { structure }\end{array}$ \\
\hline RS-RAE (2004: 5) & $\begin{array}{l}\text { Nanotechnologies are the design, characterization, } \\
\text { production and application of structures, devices and } \\
\text { systems by controlling shape and size at the nanometre } \\
\text { scale }\end{array}$ \\
\hline Tegart (2004: 364) & $\begin{array}{l}\text { We can define nanotechnology as: 'materials and systems } \\
\text { whose structures and components exhibit novel and } \\
\text { significantly improved physical, chemical and biological } \\
\text { properties, phenomena, and processes due to their } \\
\text { nanoscale size' }\end{array}$ \\
\hline $\begin{array}{l}\text { Toi Te Taiao: the } \\
\text { Bioethics Council } \\
(2003: 5)\end{array}$ & $\begin{array}{l}\text { 'Nanotechnology' is a collective term for a set of } \\
\text { technologies, techniques and processes involving } \\
\text { manipulation and characterisation of matter on the scale } \\
\text { of atoms and molecules }\end{array}$ \\
\hline
\end{tabular}


(2004: 17) contrasts two of the most frequently mentioned philosophical visions of nanotechnology; the 'atom-by-atom-manipulation' and 'selfassembly' (or 'self-organization'). He argues that it first came from the arena of scanning probe microscopy and resulted in Drexler's 'top-down' vision of self-assemblers. It is high precision and has total human control, in classical mechanical terms. In contrast, 'self-assembly' has a longer history, has a predominantly chemical process base, and is more reliant on what has been termed 'nature' enabling chemical synthesis to self-assemble. As well as these diametric philosophical stances, are the interpersonal debates and dynamics between leaders in the nanotechnology field. Examples of such interpersonal debates have been presented by commentators such as Glimell (2004: 235) who carefully and eloquently interprets the arguments of leading lights such as Eric Drexler, Mark Suchman, Mihail Roco, Richard Feynman, Bill Joy, Richard Smalley and Pat Mooney, and adds to this the broader influential comments of even Prince Charles and Michael Crichton.

The more clinical definitions of nanotechnology in Table 1.1 should be put alongside the philosophical, rhetorical, political and post-modern meanings popularly adopted. Indeed, to the degree that nanotechnology enters the policy and commercial advertising domains, there are, by definition, a host of accompanying language games going on. Nanotechnology becomes a linguistic pawn in the desire for differentiated policies, products or even personalities, rather than a scientific descriptor. Science grants, for instance, get a sexed-up 'nano' label, nanotechnology research is framed as an economic solution rather than a subject of inquiry, and nanotechnology is seen as akin to an uncontrollable 'virus' by policy activists. Importantly, in the chaotic and media driven world of advertising and policy news, it is crucial to recognize that it is not always easy to separate the clinical use of nanotechnology from the rhetorical. It is not easy to see the science and differentiate it from the imagery of either pro-nano policy waffle or anti-nano marketing. The potential for multiple language games with 'nanotechnology' is huge and demands heightened vigilance.

In retrospect, perhaps the vagaries of defining nanotechnology are not so surprising given that nanotechnology discourse deals with everything from existing proven sciences of today through to the futuristic hopes and dreams of creative visionaries. But having said this, the 'lack of uniform definitions for nanotechnology' (ETC Group, 2005: 7) is in itself problematic from a regulatory perspective. For regulatory frameworks to evolve at the national or international level, a degree of 'technical standardization' must first occur. Without some degree of consensus on definitions, common nomenclature and standards for classification and testing of nanotechnology and nanomaterials, it will be extremely 
challenging to define or classify the object or processes to be regulated. In recognition of the need for a common language for nanotechnology the International Organization for Standardization (ISO), a voluntary standards development body, established ISO/TC 229 Nanotechnologies in 2005 (ISO, 2005a). The aim of the technical committee is to develop the 'international standards for the innovatory field of nanotechnologies'. The ISO believe that 'by giving nanotechnologists a common language and processes, standardization will facilitate safer and faster product development and will enable interoperable end-products' (ISO, 2005b). Addressing the standardization challenges posed by nanotechnology is an important first stage in both national and international regulatory development processes that will be further discussed in this book.

\section{CONCEPTUAL FRAMEWORKS FOR REGULATING NANOTECHNOLOGY}

What conceptual frameworks are available to assist us in better understanding how products incorporating nanotechnology are currently being regulated, and may be regulated in the coming years?

We should first recognize that the notion of regulation is wider than simply new legislative rules. As a consequence, a broad framework for understanding regulatory options for nanotechnology is needed. A functional starting point is the seminal work of Ayres and Braithwaite (1992), in which they argued that a range of regulatory strategies is possible. Their framework outlining this continuum of regulatory responses was the 'Pyramid of regulatory strategies' illustrated in Figure 1.1.

The two dimensional pyramid represents the interactions between regulators and regulated entities, in terms of the range of actions and tools available to the regulatory agency. At the base of the pyramid are forms of 'soft' regulation, including self-regulation, persuasion and negotiation, and it is here that Ayres and Braithwaite (1992) suggest that most of the regulatory action occurs. As one moves towards the apex of the pyramid, potential regulatory strategies may include, for example, enforced self-regulation such as codes of practice, and towards forms of command regulation. At the apex of the pyramid sits the less flexible options contained within the 'hard' law, which provides regulatory agencies with the ability to respond to noncompliance if and when it occurs. The flexibility of tools and actions contained within the conceptual framework has resulted in the pyramid having achieved broad applicability within many regulatory arenas.

How might this conceptual regulatory framework be applied to nanotechnology? Bowman and Hodge (2006a) have suggested a more 


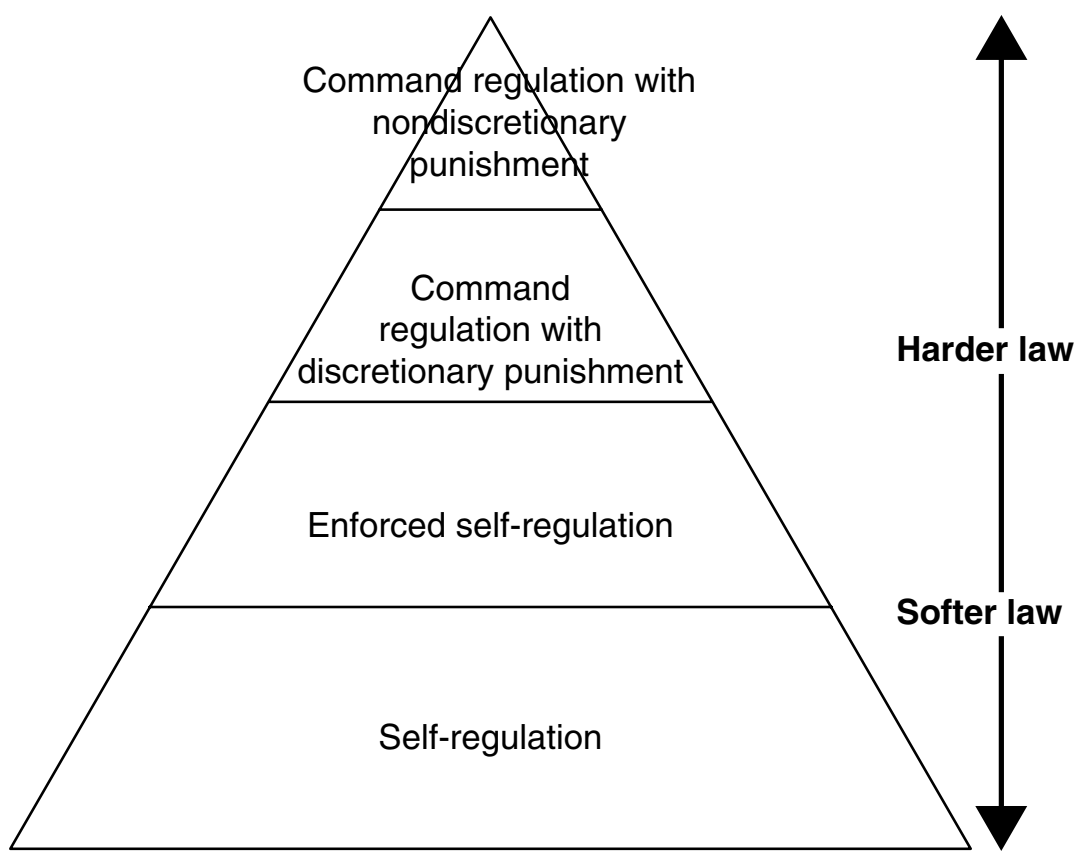

Figure 1.1 Example of Ayres and Braithwaite's (1992) enforcement pyramid

sophisticated version of this enforcement pyramid for conceptualizing future nanotechnology products, as illustrated in Figure 1.2.

Bowman and Hodge (2006a) suggest six regulatory frontiers: product safety, privacy and civil liberties, occupational health and safety $(\mathrm{OH} \& \mathrm{~S})$, intellectual property (IP), international and environmental law. For each specific frontier, application of the 'enforcement pyramid' proposed by Ayres and Braithwaite suggests that a range of regulatory mechanisms are possible, and that while hard law may well be at the centre of regulatory concerns, it is far from the only response available from governments. Also, Figure 1.2 suggests that any regulatory response will be made within the broader context of public policy concerns and international norms in which stakeholder dialogue occurs. Such a dialogue would clearly encompass a wide range of philosophical, social and ethical issues as well as the scientific and commercial matters usually dominating the industrial nanotechnology discourse.

An alterative conceptual framework might draw on the work of Abbott et al. (2006a). They suggest that the issue of how we regulate a technology involves consideration of a huge diversity of risks, over long time periods 


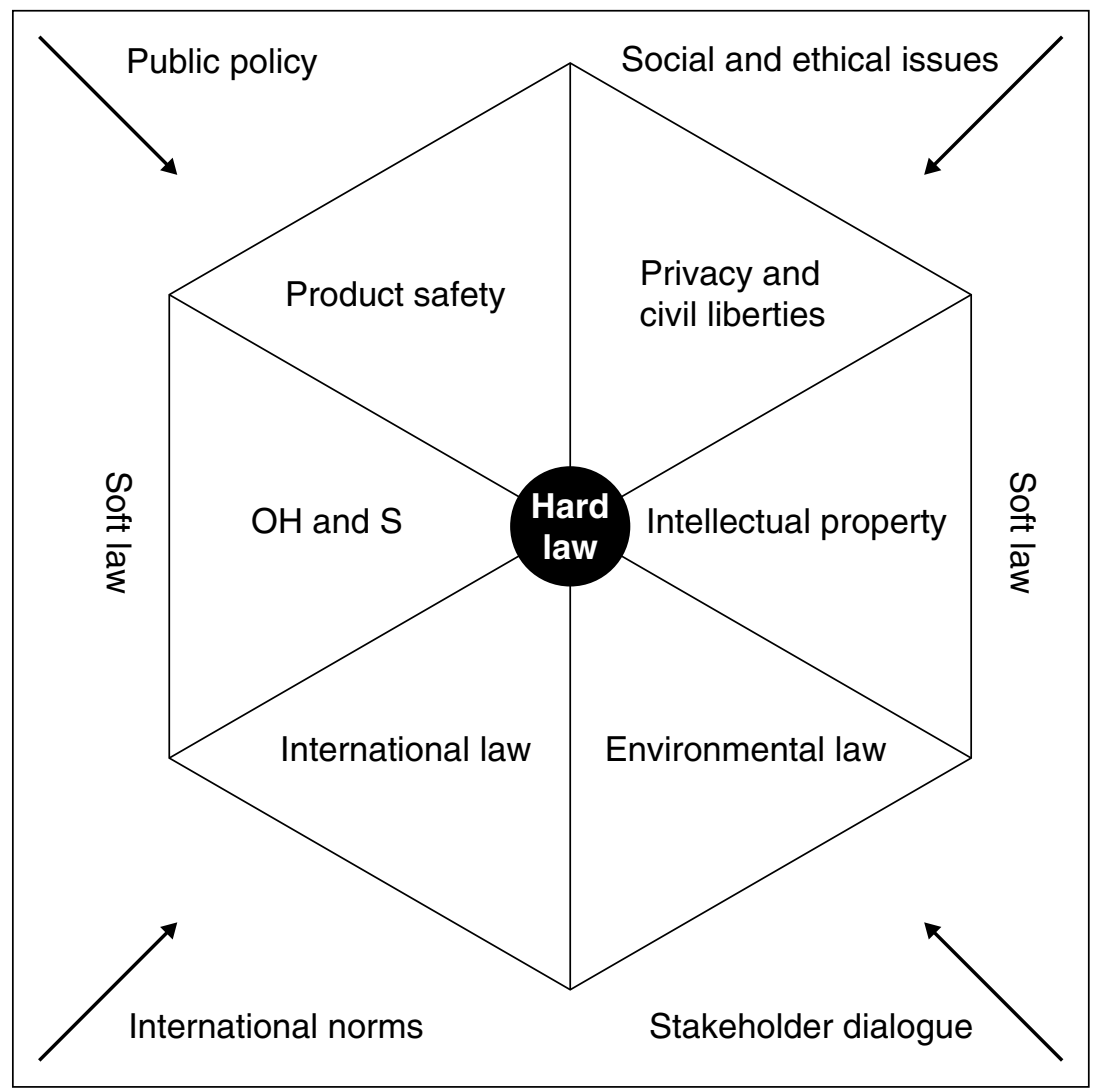

Figure 1.2 A conceptual model for the regulatory frontiers of nanotechnology

and through a range of dimensions and actors. So, should we regulate now? Or wait? Should it be at the national level or international? And so on. Abbott et al. (2006a) suggest that many of these dichotomies are false - in that new governance models incorporating 'soft law' options can provide a way forward, so that at the international level for example, transnational actors, epistemic communities and self-regulatory mechanisms can all contribute to the international regulatory framework. Such regulatory regimes, in their view, can even be less costly, more focused on science and more flexible than traditional state based, prescriptive 'hard law' approaches. Thus, over time, short term risks are met by existing legal frameworks, with new regimes progressively taking the form of expert groups, traditional dialogue and codes of conduct. In the medium term, emerging problems 
Table 1.2 Conceptual framework for thinking about nanotechnology regulation

\begin{tabular}{llll}
\hline Time & Problem & Response & Example \\
\hline Short term & $\begin{array}{l}\text { Uncertainty, } \\
\text { flexibility }\end{array}$ & Expert groups & IPCC/ISO \\
& & $\begin{array}{l}\text { Transgovernmental } \\
\text { dialogue }\end{array}$ & $\begin{array}{l}\text { International } \\
\text { dialogue for } \\
\text { responsible R\&D }\end{array}$ \\
& & Codes of conduct & $\begin{array}{l}\text { Asilomar, Foresight } \\
\text { Vienna Convention }\end{array}$ \\
Medium term & \multirow{2}{*}{ Emerging problems } & $\begin{array}{l}\text { Framework } \\
\text { Convention }\end{array}$ & Soft Law \\
Long term & \multirow{2}{*}{ Concrete problems } & Hard Law & $\begin{array}{l}\text { Stockholm, } \\
\text { Montreal }\end{array}$ \\
& & & Arms Control, SPS \\
\hline
\end{tabular}

surface and framework conventions are negotiated to deal with specific issues (such as the Vienna Convention on the Protection of the Ozone Layer), while in the longer term, concrete problems become clearer. Such issues are then eventually covered by both soft law and hard law (in a similar vein to the Ayres and Braithwaite pyramid).

Putting these elements together as an overall frame might provide the conceptual picture presented verbally by Abbott et al. (2006a). Their framework neatly merges potential regulatory responses from government to the major dimensions of time and uncertainty.

It does not, however, cover all relevant dimensions. Several additional elements could also be sensibly incorporated into conceptual frames, including for instance:

1. Technology (or product) life cycle (ranging from the planning phase, through manufacturing, and product use, to reclamation and disposal).

2. Scope of regulation (multilateral, pluri-lateral, bilateral, unilateral and national action).

3. Actors (states, national regulatory agencies, public-private partnerships, epistemic communities, researchers and business firms).

4. Legal/institutional form (interstate regimes, hard/strong law, soft/ weak law, self regulatory codes of conduct) (based on: Abbott et al., 2006a). 
A further conceptual framework for the future regulation of nanotechnology is the simple 'status quo' or 'do nothing' option. ${ }^{6}$ The premise here is that we should rely on existing regulatory institutions and law. While this frame appears to be the least pro-active, it recognizes that nanotechnology is still an evolving technology, as distinct from one which has already emerged fully blown. This regulatory option also acknowledges the fact that many nanotechnology products, along with any health and welfare implications, may well be effectively covered through existing legislative and regulatory arrangements. Such considerations would need to be balanced against what is known about nanotechnology risks, as well as easy political charges that the government was being lazy, managing its own ignorance and using citizens 'as guinea pigs' (Fleming, 2006).

So, where does all this leave us? Clearly, the multidisciplinary and heterogeneous nature of nanotechnology is likely to require a number of different regulatory and enforcement approaches to adequately oversee future developments. Regulation will undoubtedly be shaped by a wide-ranging external dialogue of social, ethical and public policy concerns and international norms involving many actors and forums.

\section{SOME ITEMS FOR THE NANOTECHNOLOGY REGULATION RESEARCH AGENDA}

The RS-RAE's (2004) report examining the opportunities and uncertainties presented by nanotechnology has encouraged the increased publication of theoretical works examining ELS aspects of the emerging technology. Nonetheless, it should be acknowledged that a number of theoretical works had already been published prior to this looking at the regulatory challenges posed by nanotechnology. This included for example Forrest (1989), Fiedler and Reynolds (1994), Reynolds (2002, 2003) and Wood et al. (2003). More recent commentators who have considered questions of whether and how governments should regulate nanotechnology have included Hodge and Bowman (2004), Pinson (2004), Wejnert (2004), the ELI (2005), Abbott et al. (2006a, b), Bowman and Hodge (2006b) and Davies (2006). ${ }^{7}$ The aim of this book is to build on these insights, adopting an international perspective, to better define the regulatory frontiers which are likely to challenge us in the future.

The themes that this current book raises revolve around continuing historical perspectives from emerging technologies, the lessons - both positive and negative - that may be learnt from regulating earlier technologies, ethical considerations associated with technologies such as nanotechnology, including for example, the 'nano-divide', the role of public engagement 
processes in informing the citizenry and in governmental policy learning, the political economy of technology regulation, democratic governing mechanisms including for example, consideration of the public interest, the role of current legislation, the question of risk, and how different jurisdictions and multilateral organizations are currently grappling with the challenges of nanotechnology.

The specific questions to be addressed in this book are many and varied. For example:

1. From historical, philosophical and ethical perspectives, in what ways does nanotechnology differ from earlier technologies?

2. What lessons may be learned from our past in regulating technologies, and how should a better understanding of technology development inform our actions in relation to future regulatory options for nanotechnology?

3. From a scientific perspective, what makes nanotechnology 'new' or different from earlier technologies, and what are the implications of the novelty associated with this emerging technology?

4. How do, and how should, governments engage in dialogue and policy learning with citizens in respect to new technology; and how may they best serve the public interest in doing so?

5. What activities are governments undertaking to meet these goals? And what can be learned from the reality of the body politic in terms of technology regulation?

6. From a regulatory perspective, how do products incorporating nanotechnology differ from conventional products; and how are governments around the world grappling with the challenges posed by nanotechnology?

7. Within the international arena, what roles are multilateral organizations playing in addressing concerns associated with nanotechnology; and what mechanisms are available to these bodies to assist in governing the emerging technology?

8. And as we move forward, which public, private and non-governmental actors are likely to be the most influential as regulatory frameworks evolve?

\section{STRUCTURE OF THIS BOOK}

This book sets out to address these questions and extend them. It does so by placing particular emphasis on the lessons of earlier technology advances, and by broadly considering the ELS issues entwined within the 
development of the nanotechnology family. A key aim of the book is to remain broadly accessible and inform readers interested in nanotechnology about policy and governance issues associated with technology development and regulation.

\section{CONCLUSIONS}

Nanotechnology is attracting large annual global investments from the public and private sectors, and appears to be the next technology to transform our society. While its promises are big, nanotechnology has also been subject to criticism and serious concerns; there are indeed many big questions for this small technology. First, the successful commercialization of nanotechnology requires the science and reality of achievements to date, to be carefully separated from the science fiction and rhetoric of the future. Second, consumers and citizens must be assured that nanotechnology will be effectively regulated as the technology moves forward. Third, while the technology offers exciting new products and opportunities, its likely social, health and environmental impacts must be clarified in order to intelligently govern the science and its commercial applications.

At present, nanotechnology is challenging scientists, governments, regulatory bodies, governance and regulatory scholars alike. It is therefore crucial that governments learn the lessons from the development of previous technologies and products, such as GMOs and asbestos, and adopt an integrated approach to the regulation of this emerging technology.

Nanotechnology is likely to have a major impact across many aspects of society, and permeate many jurisdictions. On the technological front, governments will need to learn as quickly as industry innovates if they wish to govern better than has been the case in the past. And on the governance front, we know that citizens have over the past few decades demanded governments dissolve bureaucracies and deliver better services. The future into which nanotechnology regulation will emerge, will continue to see such pressures and as well, will also see heightened new demands on government for better regulation and a safer world in which to live.

\section{NOTES}

1. 'It is no accident that the NNI [the US National Nanotechnology Initiative] is a nanotechnology and not a nanoscience initiative' according to Baird and Shew (2004: 150). They note that 'it is the technological promise of work at the nanoscale that is compelling' and that 'a central aim of the NNI is to quickly move nanoscientific discoveries into commercial development'. Citing the \$US50 million grant to the Massachusetts Institute of 
Technology from the US Army to develop 'nano-uniforms' (which can stop bullets, monitor health, make the wearer stronger and can communicate), Baird and Shew quote Edwin Thomas who stated that the Army was not interested in papers, in Science and Nature: 'They wanted real stuff'.

2. Having made this observation, the reality is that we do not currently have any accurate measure of the number of such applications. There are currently no legal requirements for companies to register or label such products on a national basis. And as a result, estimates vary from the ELI estimate of 500-700 commercially available nano-products down to the online inventory initiated by the Woodrow Wilson International Center, which suggests that closer to 300 items are being advertised as nano-products. In any event, these estimates may be wildly inaccurate, because they either second guess the real extent of nano-product commercialization, or else it may be fashionable to market products as nano-based whether they are or not. As an example of the latter, Berube (2004: 184) lists numerous companies trading through 'nano' marketing since 1993, including company divisions entitled Nanotainment, for consulting services, and Nanoventures, for investment services. Citing May (1995) he leaves little doubt as to his judgement, stating categorically that 'most uses of nano don't have anything to do with molecular nanotechnology'.

3. Johnson (2004: 226) observes that nanotechnologies are probably more a re-labelling and policy reframing of science than a single new coherent technology per se. It is, as she puts it, 'the jewel in the crown of current publicly supported science . . . and is a nearly perfect fit for what both companies and the government expect from science'. At the centre of nanotechnology's power is its claim 'to be tomorrow's economic engine'.

4. Having said this, public policy decision making has never been a linear sequential process governed by the results of so called 'rational decision tools' such as benefit-cost analysis, risk assessments or complex computer modelling. Public policies, in the words of Parsons (1995) have owed as much to 'academic scribblers and madmen in authority' as they have to any more rational and logical policy arguments. This is not to say that sensible public policy is not a desirable end goal, just that the process by which sensible policies are reached are usually complex and extended affairs reliant as much on community values and connections as on any quantitative logics or rationale.

5. Hodge et al. (2005) documents the sorry but complex regulatory history of asbestos. In 1898, a woman inspector of factories in the UK filed one of the earliest reports citing the health hazard of asbestos dust for workers. This was followed by two decades of medical reports of the poor health effects of asbestos, and in 1918, Canadian insurance companies refused to insure asbestos workers due to the health hazard of asbestos. Through the 1920s, much scientific research was undertaken on the health effects of asbestos, so that by the late 1920s, asbestos was widely accepted as a cause of asbestosis. It was not until 1943 that the German Government deemed asbestos lung cancer to be an industrial disease, and therefore, compensatable. In the 1960s asbestos became widely accepted as a cause of mesothelioma, and asbestos became a (populist) political issue in the UK and USA. In 1979 a UK government Inquiry recommended the banning of 'blue asbestos' and effective enforcement of asbestos dust emission regulations. It was not until after the world's largest asbestos company filed for bankruptcy in 1982 that some governments finally banned the use of all forms of asbestos; France in 1997, the UK in 1998 and the EU in 1989 (Gee and Greenberg, 2002). Interestingly, the continued commercial power of asbestos revenues gained from developing countries was evident even over the past decade when a WTO dispute was filed by Canada against the UK and the EU, in which they argued that the asbestos ban constituted a trade barrier. The WTO Dispute Panel and WTO Appellate Body found in favour of the UK and EU.

6. Rather than the strict 'do-nothing' option, this is likely in reality to mean a 'do-theminimum' option.

7. See also: Miller (2003); Wardak (2003); Bennett (2004); Castro (2004); Balbus et al. (2005); Elliott (2005); Hodge et al. (2005); Oud (2005). For increasing media discussion on nanoregulations, see: Bullis $(2005,2006)$; Weiss $(2005,2006)$. For a more general discussion on the interface between nanotechnology and the law, see for example: Munich Re Group (2002); Miller (2004, 2005); Swiss Re (2004); Allianz (2005). 


\section{REFERENCES}

Abbott, K., S. Gopalan, G. Marchant and D. Sylvester (2006a), 'Transnational models for the regulation of nanotechnology', paper presented at the International Studies Association Conference, San Diego, 22-25 March.

Abbott, K., G. Marchant and D. Sylvester (2006b), 'A framework convention for nanotechnology?', Environmental Law Reporter, 36, 10931-42.

ABC Radio National (2004), 'Nanotechnology: nature's toy box', Background Briefing, 14 November, Sydney.

Advanced Nanotechnology Limited (2005), 'ZinClear - the nanofine zinc oxide for cosmetic clarity and broad spectrum UV protection', accessed 30 March at www.advancednanotechnology.com/.

Aitken, R., K. Creely and C. Tran (2004), Nanoparticles: An Occupation Hygiene Review, Edinburgh: Institute of Occupational Medicine for the Health and Safety Executive.

Allianz (2005), Small Sizes that Matter: Opportunities and Risks of Nanotechnologies, Munich: Allianz Centre for Technology and OECD.

Altmann, J. (2006), Military Nanotechnology: Potential Applications and Preventive Arms Control, London: Routledge.

Ayres, I. and J. Braithwaite (1992), Responsive Regulation: Transcending the Deregulation Debate, New York: Oxford University Press.

Baird, D. and A. Shew (2004), 'Probing the history of the scanning tunneling microscopy', in D. Baird, A. Nordmann and J. Schummer (eds), Discovering the Nanoscale, Amsterdam: IOS Press, pp. 145-56.

Baird, D., A. Nordmann and J. Schummer (eds) (2004), Discovering the Nanoscale, Amsterdam: IOS Press.

Balbus, J. M., R. Denison, K. Florini and S. Walsh (2005), 'Getting nanotechnology right the first time', Issues in Science and Technology, Summer, 65-71.

Bennett, M. (2004), 'Does existing law fail to address nanotechnoscience?', IEEE Technology and Society Magazine, Winter, 27-32.

Berube, D. M. (2004), 'The rhetoric of nanotechnology', in D. Baird, A. Nordmann and J. Schummer (eds), Discovering the Nanoscale, Amsterdam: IOS Press, pp. 173-92.

Better Regulation Task Force (2003), Scientific Research: Innovation with Controls, London: Better Regulation Task Force.

Bowman, D. and G. Hodge (2006a), 'Nanotechnology: mapping the wild regulatory frontier', Futures, 38, 1060-673.

Bowman, D. and G. Hodge (2006b), 'A small matter of regulation: an international review of nanotechnology regulation', Columbia Science and Technology Law Review, 8, 1-32.

Brumfiel, G. (2003), 'Nanotechnology: a little knowledge . . ', Nature, 424, 246.

Bullis, K. (2005), 'Can EPA regulate nano?', Technology Review - An MIT Enterprise, accessed 20 December at http://www.technologyreview.com/Nanotech/16068/.

Bullis, K. (2006), 'New nano law?', Technology Review - An MIT Enterprise, accessed 17 January at www.technologyreview.com/Nanotech/16152/.

Cao, G. (2004), Nanostructures \& Nanomaterials: Synthesis, Properties and Applications, London: Imperial College Press.

Castro, F. (2004), 'Legal and regulatory concerns facing nanotechnology', Journal of Chicago-Kent Intellectual Property, 4(1), 140-6. 
Crandal, B. C. (1996), Nanotechnology: Molecular Speculation on Global Abundance, Cambridge, MA: MIT Press.

Davies, J. C. (2006), Managing the Effects of Nanotechnology, Washington, DC: Woodrow Wilson International Center for Scholars.

Department for Environment, Food and Rural Affairs (DEFRA) (2005), Characterising the Potential Risks Posed by Engineered Nanoparticles: A First UK Government Research Report, London: HM Government.

Department of Trade and Industry and Office of Science and Technology (2002), New Dimensions for Manufacturing: A UK Strategy for Nanotechnology, London: DTI and OST.

Drexler, K. E. (1986), Engines of Creation: The Coming Era of Nanotechnology, New York: Anchor Books.

Drexler, K. E. (2001), 'Machine-phase nanotechnology', Scientific American, 285(3), 74-5.

Drexler, K., C. Peterson and G. Pergamit (1993), Unbounding The Future: The Nanotechnology Revolution, New York: Quill Books.

Einsiedel, E. F. and L. Goldenberg (2004), 'Dwarfing the social? Nanotechnology lessons from the biotechnology front', Bulletin of Science, Technology and Society, 24, 28-33.

Elliott, E. D. (2005), 'Regulate nano now', The Environmental Forum, July/August, 43.

Environmental Law Institute (ELI) (2005), Securing the Promise of Nanotechnology: Is US Environmental Law Up to the Job?, Washington, DC: Environmental Law Institute.

Environmental Protection Agency (2005), 'US environmental protection agency: external review draft - nanotechnology white paper', prepared for the US EPA by members of the Nanotechnology Workgroup, Washington, DC: EPA.

ETC Group (2003), The Big Down: Atomtech - Technologies Converging at the Nano-scale, Ottawa: ETC Group.

ETC Group (2004), Down on the Farm, Ottawa: ETC Group.

ETC Group (2005), Nanotech's 'Second Nature' Patents, Ottawa: ETC Group.

European Commission - Community Health and Consumer Protection (2004), Nanotechnologies: A Preliminary Risk Analysis on the Basis of a Workshop Organized in Brussels on 1-2 March 2004 by the Health and Consumer Protection Directorate General of the European Commission (Mapping out Nano Risks), Brussels: European Commission.

Feynman, R. (1959), 'There's plenty of room at the bottom', paper presented to the arrival meeting of the American Physical Society, California Institute of Technology, 29 December, accessed at www.its.caltech.edu/ feynman/.

Fiedler, F. A. and G. H. Reynolds (1994), 'Legal problems of nanotechnology: an overview', Southern California Interdisciplinary Law Journal, 3, 594-629.

Fleming, N. (2006), 'Women buying creams of tiny particles "Used as guinea pigs"', The Daily Telegraph, 5 May, p. 6.

Forrest, D. (1989), Regulating Nanotechnology Development, Palo Alto, CA: Foresight Institute.

Gee, D. and M. Greenberg (2002), 'Asbestos: from "magic" to malevolent mineral', in P. Harremo, D. Gee, M. MacGarvin, A. Stirling and S. G. V. Wynne (eds), Late Lessons From Early Warnings: The Precautionary Principle 1896-2000, Copenhagen: European Environment Agency. 
Glimell, H. (2004), 'Grand visions and Lilliput politics: staging the exploration of the "Endless frontier", in D. Baird, A. Nordmann and J. Schummer (eds), Discovering the Nanoscale, Amsterdam: IOS Press, pp. 231-46.

Gubrud, M. A. (1997), 'Nanotechnology and international security', paper presented at the Fifth Foresight Conference on Molecular Nanotechnology, 5-8 November, Palo Alto, CA.

Hindmarsh, R. and H. Gottweis (2005), 'Recombinant regulation: the Asilomar legacy 30 years on', Science as Culture, 14, 299-307.

Hodge, G. and D. Bowman (2004), 'Governing nanotechnology: setting the regulatory agenda', The Journal of Contemporary Issues in Business and Government, 10(2), 18-33.

Hodge, G., D. Bowman and P. Binks (2005), 'Governing the invisible: the new regulatory frontiers of nanotechnology', presented at the Integrated Governance: Linking up Government, Business and Civil Society, Prato, 26-29 October.

House of Lords (2000), Science and Society, Third Report, London: House of Lords.

Hunt, G. and M. D. Mehta (2006), Nanotechnology: Risk, Ethics and Law, London: Earthscan Publishing.

ISO (2005a), 'New ISO committee will develop standards for nanotechnologies', accessed 19 December at www.iso.org.

ISO (2005b), 'ISO launches work on nanotechnology standards', accessed 16 November at www.iso.org.

Jasanoff, S. (2005), Designs on Nature: Science and Democracy in Europe and the United States, Princeton, NJ: Princeton University Press.

Johnson, A. (2004), 'The end of pure science: science policy from Bayh-Dole to the NNI', in D. Baird, A. Nordmann and J. Schummer (eds), Discovering the Nanoscale, Amsterdam: IOS Press, pp. 217-30.

Kearnes, M., R. Grove-White, P. Macnaghten, J. Wilsdon and B. Wynne (2006), 'From bio to nano: learning lessons from the UK agricultural biotechnology controversy', Science as Culture, 15, 291-307.

Loder, N. (2004), 'Small wonders', Bulletin, 3-4.

Lux Research Inc (2005), 'Nanotechnology: where does the US stand?', in Testimony Before the Research Subcommittee of the House Committee on Science, New York: Lux Research Inc.

Lux Research Inc (2006), The Nanotech Report (4th edn), New York: Lux Research Inc.

MacNaghten, P., M. Kearnes and B. Wynne (2005), 'Nanotechnology, governance and public deliberation: what role for the social sciences?', Science Communication, 27(2), 268-91.

Marchant, G. E. and D. J. Sylvester (2006), 'Transnational models for regulation of nanotechnology', The Journal of Law, Medicine \& Ethics, 34(4), 714-25.

May, T. (1995), 'Nanometrics - NANO', Sci.nanotech Discussion List, accessed at www.planchet.rutgers.edu.

Mehta, M. D. (2004), 'From biotechnology to nanotechnology: what can we learn from earlier technologies?', Bulletin of Science, Technology \& Society, 24(1), 34-9.

Miller, J. (2003), 'Beyond biotechnology: FDA regulation of nanomedicine', The Columbia Science and Technology Law Review, (4), 5-46.

Miller, S. E. (2004), 'Converging technologies: a matter of torts: why nanotechnology must develop processes of risk analysis', New York Law Journal, 5 October, 5. 
Miller, S. E. (2005), 'Converging technologies: the frontier of science: a conversation with big leaders in the small world of nanotech', New York Law Journal, 1 February, 5.

Munich Re Group (2002), Nanotechnology - What is in Store for Us?, Munich: Munchen Re.

National Nanotechnology Initiative (2001), Nanotech Facts: What is Nanotechnology?, Washington, DC: NNI.

Oud, M. (2005), 4th Nanoforum Report: Benefits, Risks, Ethical, Legal and Social Aspects of Nanotechnology - Part 7: The Need for and Rise of New Legislation and Regulation Caused by the Emergence of Nanotechnology, London: Nanoforum.org - European Nanotechnology Gateway.

Parsons, W. (1995), Public Policy: An Introduction to the Theory and Practice of Policy Analysis, Cheltenham: Edward Elgar.

Perkel, J. M. (2002), 'Nanotech dreams', The Scientist, 16(5), 34-6.

Pinson, R. D. (2004), 'Is nanotechnology prohibited by the biological and chemical weapons conventions?', Berkeley Journal of International Law, 22(2), 279-309.

Prime Minister's Science Engineering and Innovation Council (PMSEIC) (2005), Nanotechnology: Enabling Technologies for Australian Innovative Industries, Canberra: Commonwealth of Australia.

Ratner, D. and M. A. Ratner (2003), Nanotechnology and Homeland Security: New Weapons for New Wars, New York: Prentice Hall.

Rayner, S. (2004), 'The novelty trap: why does institutional learning about new technologies seem so difficult?', Industry and Higher Education, December, 349-55.

Rietman, E. A. and M. Andrews (2001), Molecular Engineering of Nanosystems, New York: Springer.

Reynolds, G. H. (2002), Forward to the Future: Nanotechnology and Regulatory Policy, San Francisco, CA: Pacific Research Institute.

Reynolds, G. H. (2003), 'Nanotechnology and regulatory policy: three futures', Harvard Journal of Law \& Technology, 17(1), 180-209.

Roco, M. C. (2003), 'Nanotechnology: convergence with modern biology and medicine', Current Opinion in Biotechnology, 14, 337-46.

Roco, M. C. and W. S. Bainbridge (eds) (2001), Societal Implications of Nanoscience and Nanotechnology, New York: Springer.

Royal Society and Royal Academy of Engineering (RS-RAE) (2004), Nanoscience and Nanotechnologies: Opportunities and Uncertainties, London: RS-RAE.

Schummer, J. (2004), 'Interdisciplinary issues in nanoscale research', in D. Baird, A. Nordmann and J. Schummer (eds), Discovering the Nanoscale, Amsterdam: IOS Press, pp. 9-20.

Smalley, R. (2001), 'Of chemistry, love and nanobots', Scientific American, 285(3), 76-7.

Suchman, M. (2002), 'Social science and nanotechnologies', presentation to Nanotechnology: Revolutionary Opportunities and Societal Implications, 3rd Joint EC/NSF Workshop on Nanotechnology, Leece, pp. 95-9.

Swiss Re (2004), Nanotechnology: Small Matter, Many Unknowns, Geneva: Swiss Re.

Taniguchi, N. (1974), 'On the basic concept of nanotechnology', in Proceedings of the International Congress on Production Engineering, Tokyo.

Tegart, G. (2004), 'Nanotechnology: the technology for the twenty-first century', Foresight, 6(6), 364-70. 
Toi Te Taiao: the Bioethics Council (2003), Nanotechnology: Report of Toi Te Taiao: the Bioethics Council to the Minister for the Environment, Wellington: Toi Te Taiao.

Turk, V. (2005), 'Nanologue - facilitating dialogue between research, business and society', paper presented at the EuroNanoForum Conference, 7 September, Edinburgh.

University of New South Wales (2006), A Bathroom that Cleans Itself, Sydney: The University of New South Wales, accessed 7 February at www.unsw.edu.au.

Vacca, J. (2006), Nanotechnology: Materials, Systems and Processes at the NanoScale, London: Butterworth-Heinemann.

Wardark, A. (2003), Nanotechnology \& Regulation: A Case Study using the Toxic Substance Control Act (TSCA), Washington, DC: Foresight Institute and Woodrow Wilson International Centre for Scholars.

Weiss, R. (2005), 'Nanotechnology regulation needed, critics say', accessed 5 December at www. Washingtonpost.com.

Weiss, R. (2006), 'Stricter nanotechnology laws are urged', accessed 11 January at www.Washingtonpost.com.

Wejnert, J. (2004), 'Regulatory mechanisms for molecular nanotechnology', Jurimetrics, 44, 323-50.

Whiteside, G. M. (2003), 'The "right" size in nanobiotechnology', Nature Biotechnology, 21(9), 1161-5.

Whiteside, G. and C. Love (2001), 'The art of building small', Scientific American, 285(3), 38-47.

Wolfson, J. R. (2003), 'Social and ethical issues in nanotechnology: lessons from biotechnology and other high technologies', Biotechnology Law Report, 22, 376-96.

Wood, S., R. Jones and A. Geldart (2003), The Social and Economic Challenges of Nanotechnology, London: Economic and Social Research Council.

Woodrow Wilson International Center for Scholars (2006), Nano-Product Inventory - Analysis of On-Line Inventory, Woodrow Wilson International Center for Scholars: Washington, DC accessed 14 May at www.advancednanotechnology. $\mathrm{com} /$. 